\title{
Encounters in and with Summer Camps-Happy Childhood, Alternative Bildung, or What?
}

\author{
Iuliia Afonkina $^{1}{ }^{\mathbb{D}}$, Werner Bigell ${ }^{2, *} \mathbb{C}$, Valerii Chernik $\left.{ }^{1} \mathbb{(}\right)$, Torun Granstrøm Ekeland ${ }^{2}$, Tatiana Kuzmicheva ${ }^{1}(\mathbb{D}$, \\ Kirsten Elisabeth Stien ${ }^{2}$ and Herbert Zoglowek ${ }^{3}$ (D) \\ 1 Institute of Psychology and Pedagogy, Murmansk Arctic State University, 183038 Murmansk, Russia; \\ kafspip@masu.edu.ru (I.A.); kafped@masu.edu.ru (V.C.); kuzmicheva.tatyana@masu.edu.ru (T.K.) \\ 2 Department for Teacher Education and Pedagogy, UiT-The Arctic University of Norway, 9509 Alta, Norway; \\ torun.g.ekeland@uit.no (T.G.E.); kirsten.e.stien@uit.no (K.E.S.) \\ 3 School of Sport Sciences, UiT-The Arctic University of Norway, 9509 Alta, Norway; \\ Herbert.Zoglowek@uit.no \\ * Correspondence: werner.bigell@uit.no
}

check for updates

Citation: Afonkina, I.; Bigell, W.; Chernik, V.; Ekeland, T.G.;

Kuzmicheva, T.; Stien, K.E.;

Zoglowek, H. Encounters in and with Summer Camps-Happy Childhood, Alternative Bildung, or What? Educ. Sci. 2021, 11, 567. https://doi.org/ 10.3390/educsci11100567

Academic Editor: Anne

Beate Reinertsen

Received: 4 August 2021

Accepted: 8 September 2021

Published: 23 September 2021

Publisher's Note: MDPI stays neutral with regard to jurisdictional claims in published maps and institutional affiliations.

Copyright: (c) 2021 by the authors. Licensee MDPI, Basel, Switzerland. This article is an open access article distributed under the terms and conditions of the Creative Commons Attribution (CC BY) license (https:/ / creativecommons.org/licenses/by/ $4.0 /)$.

\begin{abstract}
Although they commonly are associated with recreation, summer camps for children can be seen as educational arenas that both supplement and challenge school education. Summer camps provide education in a broad sense of bildung. The article aims at describing what is experienced in summer camps and proposes various theoretical frames for these bildung processes. The main focus is on summer camps in Russia, and we interviewed Russian informants who participated in summer camps. The findings were that learning in the camps tends to be non-instrumental, allowing room for play and experimentation for both pupils and teachers. Social learning is marked by collective elements such as camp rituals and spontaneous solidarity, both forming an individual personality. Outdoor activities are important because they connect children to nature and develop a sense of place marked by biophilia. Furthermore, nature's materiality creates a sense of being in the world, which means developing a sense of multiple relational settings, spanning from the materialities of geography, place, and objects to experiencing new social settings in the form of solidarity, ritual, and friendship.
\end{abstract}

Keywords: summer camps; bildung; relational learning; nature; materiality

\section{Introduction}

Pedagogy responds to the challenges of modern reality, characterized by social fragmentation and increasingly virtual communication. To meet these challenges, it is not always necessary to look for new solutions; instead, solutions can be found in historical models, traditions, and pedagogical practices, such as summer camps for children. Summer camps have several common characteristics: they are an opportunity to meet new friends, they are focused on social learning rather than on academic achievement, they are often run by teacher education students on a daily basis, and they are mostly set in rural or natural spaces.

The idea of taking a closer look at children's summer camps with regard to their pedagogical potential in the spirit of bildung developed during a discussion in our research group about where the ideal of bildung can still be found today. A colleague, who in recent years had volunteered in summer camps in Siberia, brought impressions from the Soviet film "Dobro Pozhalovat, ili Postoronnim vhod vospreshchyon" (Welcome, or no Trespassing) into the conversation. Even though not everyone in the discussion group was familiar with this film, all had associations of their own or had heard about summer camps. Surprisingly, many commonalities came to light, even though the discussion group was made up of participants from different countries. In addition, due to the different educational backgrounds, different approaches of viewing and assessing emerged. It can 
be said that our discussion reflected the diversity and, to a certain extent, the elusiveness of the concept of bildung. In the multi-layered analysis of Russian summer camps, a wide variety of dimensions of bildung can be discerned. We decided to follow up on this topic.

Regarding the fact that we are dealing with an institution that almost every child in the Soviet Union experienced and that remains a mass phenomenon in Russia today, also regarding the fact that teacher education students are required to do teaching practice in summer camps, the academic interest in camps appears to be reserved. A quick survey of academic literature showed that there were relatively few sources, most of which dealt with practical and organizational issues of the camps, however, with some notable exceptions using wider conceptual frames. For example, Dinke D.V. presents the idea that camps were a refuge for progressive pedagogy [1]. His finding invites further analysis of the temporal and spatial structuration of Soviet society; camps function as temporal pedagogical supplements that inspire or renew the system without fundamentally challenging it. While the camps in the Soviet Union and arguably also in contemporary Russia form a symbiosis with traditional education, seen from a Western perspective, the camps are a reminder of the fact that the bildung ideal has been undermined by the neoliberal trends of economic over-determination of education and by a cultivation of an unmoderated subjectivity demanding affirmation.

The aim of this article is to dive into the phenomenon of summer camps, followed by an investigation on bildung in this context. Our ambition is to explore pedagogical and educational values when it comes to establishing an understanding of bildung in a broad sense. By expanding on a qualitative study, consisting of ten interviews with former participants in Russian summer camps, we apply conceptual tools from pedagogy and other fields. We approach education in a broad sense as bildung, and, in such a perspective, seemingly marginal aspects such as sociability, place and setting, and the materiality of nature as well the interaction of these elements become crucial for learning.

Terms analyzing the relation to nature or the qualities of face-to-face interaction are often descriptive and tend to appeal to common experience. Materiality is such a term, but it is not reflective of universal experience. Biophilia is another descriptive term. Both terms can be partly associated with an essentially romantic understanding of nature, that nature is inherently good and human beings are a part of nature. However, we must not only understand the cultural prefiguration in the experience of nature but also the natural one. How does nature in general and geography in particular structure life and education?

The Arctic and subarctic land masses of our planet form a ring around the open sea, which has made these areas prone to cultural encounters, trade, and mobility. An example here is the Pomor trade, once stretching from Norway to California. Nature is experienced as a limit, as material obstacle and spiritual challenge, and this limitation is its greatest attraction and has repercussions on culture. Summers with their agreeable temperatures and white nights create a feeling of impermanence. The argument here is that the experience of transitoriness of temporal limits, short magical summers, synchronizes culture and leads to ritual, marked by a collective sociability. Not only is there a temporal structure creating a sense of nature, since Soviet times there has also been a spatial one, a collective change of place. In summer, workers went on vacation or moved from their housing blocks to their dacha, students worked in student brigades constructing railway lines and cities far away from home, and children were sent to summer camps.

Cultures are not mechanisms to streamline individual expression, but they facilitate expression by providing patterns for human interaction. These patterns are diverse and dynamic and may even be contradictory. The Austrian philosopher Robert Pfaller argues that rituals suspend cultural rules temporarily, that, in other words, cultures provide both rules and collective ways of breaking them [2]. In addition to this temporal structure, in this case summer culture prefigured by the northern climate, there is a spatial dimension as well. Soviet pioneer camps and many of the modern camps, often using the old installations, are located in natural environments, creating a sense of being away from one's usual life world. Michel Foucault contrasts such places to utopias, coining the term heterotopia for "places 
that do exist and that are formed in the very founding of society, which are something like counter-sites, a kind of effectively enacted utopia in which the real sites, all the other sites that can be found within the culture, are simultaneously represented, contested, and inverted" [3] (p. 24). In practice, for children, the "enacted utopia" means a place without parents and teachers (who may have a role in organizing activities), being in nature, and meeting new friends. Even though post-Soviet camps may have an academic theme such as English camp, activities are playful, and there is no teaching plan, no homework, no textbook, and no grade. Children are supervised by a collective of teacher training students, forming a camp inside the camp. They take care of order and routines and organize choreographies and games for the children.

The seclusion of the place and the synchronization and interaction through activities and rituals creates what Christoph Türcke calls "common now-time" [4] (p. 117). On the one hand, summer camps represent a return to the past, where children played outside. However, the methodical freedom that teachers in a camp setting have encourages experimentation in terms of experiential learning. Camps integrate apparently divergent aspects of bildung, away from the fragmentation and economic instrumentalization of skills and competence pedagogy. Camps encourage an exploration of one's subjectivity, but they are also arenas of exploring collective relations to nature and of social learning. While on the one hand they are spatially secluded, on the other, they have the potential for facilitating communication with others, in the form of virtual exchange between camps in different countries or regions or of physical exchange of children, students, and teachers. The experience of being limited by physical nature is the camps' greatest attraction because it invites collective playful struggle with this limitation.

Learning in summer camps is primarily social, as it is presented and illustrated in the 1964 Soviet film "Dobro Pozhalovat, ili Postoronnim vhod vospreshchyon" (Welcome, or No Trespassing). The story is about a boy who is expelled from a camp but returns and hides, receiving help in the form of food and company first from the other children and later also from student assistants and workers in the camp. Aspects of social learning here are developing spontaneous solidarity, acting collectively, and dealing with authority. These learning processes are education in a wide sense, a form of bildung.

The Russian authors of this article remember episodes of their own life in a children's camp, the romance of meeting the dawns or saying goodbye to the sun at sunset, hiking in the mountains or sporting events, when it was necessary to overcome the inevitable difficulties and show will-there was just so much that the memory kept since childhood.

One may remark: Why do you return to the subject children's camps? Isn't it the same as reinventing the wheel? Here, it seems appropriate to recall the words of the Russian scientist Vladimir Vernadskii:

"The history of science should be critically compiled by everyone in the scientific generation, and not just because our stocks are changing knowledge about the past, new forms of restoration of the past are opened. No! It is necessary to recycle the history of science scientifically, it goes back to the past again, because thanks to the development of modern knowledge about the past, one gets meaning and loses another. Each generation of scientific researchers finds in the history of science a reflection of the scientific trends of their time. Moving forward, science not only creates the new, but also inevitably reevaluates the old, experienced" [5] (p. 112). Applied to the investigation of summer camps, this means that the camps are not a fossilized remnant of the past but the product of a renegotiation between past, present, and future creating spaces of opportunities.

\section{On the History of Summer Camps}

The history of children's summer camps goes back to 1876, when Hermann Walter Bion, a pastor in Zurich, Switzerland, organized a summer holiday camp in the Alps for the children of the parishioners of his church [6]. The camp gave children the experience of another, unusual life with adventures and hikes. Recreation did not mean relaxation, as camps often included elements of rural labor. Already earlier, in the same vein, Johann 
Heinrich Pestalozzi (1801) had written about the transformative role of labor. It is not surprising that Nadezhda Krupskaya, Deputy Minister of Enlightenment and Vladimir Lenin's wife, took up the notion of an active lifestyle as an ideal for Soviet camps: "There is a rest that can give a lot both in the sense of strengthening physical strength and in the sense of growing consciousness, and there can be a rest that can only make you tired and stupid" [7] (p. 139). This means that camps were seen as places of cooperation with others and as encounters with nature in the form of recreation and labor, and that these encounters had a transformative character, not only transforming nature through labor but also facilitating the formation of individual personality and collective social identity, as we see in the development of spontaneous solidarity in the film Dobro Pozhalovat.

The underlying cultural motivation for the popularity of summer camps, however, was neither pedagogical nor political, although modified by those factors. Like the German life reform movement, it was a reaction against the living conditions created by early industrialization and urbanization. At the end of the nineteenth century, the number of street children increased in many countries in Europe and North America. Most often, they were the children of working-class, poor, and ruined people. They united in gangs, terrifying the inhabitants with their reckless and dangerous antics, which became a kind of revenge on the haves for their arbitrary treatment of the poor. There were people who understood the injustice of social segregation, sought to help the poor, and took care of street children. There were clubs for children organized by the Settlement Society. This movement was founded in 1887 in New York. Similar movements, albeit with initially different intentions, were founded in Great Britain at the beginning of the 20th century by Robert Baden-Powell (Boy Scouts) [8], and in Germany and England by Kurt Hahn [9] and operated corresponding camps. Core elements were self-government and work, and teenagers gained experience of useful leisure and positive socialization. These movements appeared in France, Belgium, Germany, Sweden, Norway, Austria, Japan, India, and Australia.

In 1906, the Settlement Society appeared in Russia. The Russian teacher Stanislav Shatsky, whose views were greatly influenced by Leo Tolstoy and John Dewey, created a summer work and recreation camp for children in one of the most socially disadvantaged areas of Moscow. The main point was the desire to help children get at least a minimum of knowledge about nature and society, to introduce them to feasible physical labor, and to develop the ability to live in a civilized society and to cooperate. Many games were organized in that camp since Shatsky considered games as the vital laboratory of childhood [10]. Working in a children's summer camp allowed him to draw the following conclusions: First, children influence each other more than the adults do. Second, all caregivers should be reduced to creating a friendly children's society. Third, the authority of the adults is only valid, useful, and high when there is no compulsory element in it. Fourth, children should feel confidence in themselves from their adults, i.e., that adults need authority not strength, but knowledge, experience, and love for children [10].

Shatsky and his associates failed to realize many of their plans in tsarist Russia. In the conditions of the reactionary policy of the tsarist authorities and the Jewish pogroms, he and his wife were forced to leave the country for a short time. He was able to implement his ideas for organizing summer camps after the Bolsheviks came to power in Russia.

Historically, summer camps can be classified as:

- $\quad$ joint work and recreation camps for children;

- military sports camps with a Spartan lifestyle;

- $\quad$ health-improving camps with the characteristics of a sanatorium.

The history of children's summer camps illuminates their main intentions, which was to compensate for the shortcomings of a child's life during the summer in a large city; life was marked by a lack of green spaces in courtyards, entrance fees for parks, unemployment, and a lack of vacation time. The target group of summer camps were weak children from poor families (sending was carried out only on the appointment of school doctors), and the most important task was the organization of food. Children were provided with milk 
as a source of additional energy, and growth, weight, and physical activity parameters were taken into account in the camps. Children were trained in household skills and personal hygiene and body care, for example making beds, cleaning rooms, mending clothes, combing hair, and brushing teeth. Children gained an understanding of the world through natural science education, travel, excursions, and agricultural work such as tending the garden and helping local farmers harvesting, as well as food gathering in the form of mushroom picking, and collecting berries and medicinal herbs. All activities created the condition for personal growth and education in the sense of bildung.

\section{Summer Camps-Another Way of Bildung?}

In addition to the discussed activities in summer camps, their setting in nature is also important. Summer camps are held outdoors, and it is no coincidence that nature is included, since nature itself is attributed with special qualities. Experiences of nature are seen as particularly conducive to learning and development, as they are based on direct, unmediated experience. Our relationship to and understanding of nature is influenced by nature-related concepts that we ourselves have experienced, learned, or adopted. The relationship of humans-as biological and cultural living beings-to nature does not only exist as a given because humans belong to nature, but it is also the result of a culturally mediated relationship. This relationship encompasses qualitatively different dimensions of mental, affective, and action-related engagement with nature [11]. The importance of nature for human development can also be seen in the "biophilia hypothesis" [12] and the psycho-pedagogical approach of Erich Fromm [13], in which personality development and personal fulfilment are to be understood in relation to our relationship with nature. Summer camps open up a variety of experiences of nature as well as social experiences related to nature, which can be reflected and discussed especially within Fromm's concept of "productive character orientation" [14].

"Biophilia is the passionate love of life and all living things; it is the desire to promote growth-be it in a person, a plant, an idea, or a social group. The biophile prefers to build something new rather than preserve the old. He wants to be more rather than to have more. He has the ability to wonder, and he prefers to experience something new rather than to find the old confirmed. He prefers to live the adventure rather than security. He is more concerned with the whole than with the parts, more with structures than summations" [15] (p. 331; own translation). The surroundings and the pedagogical implications of summer camps have the potential to realize these aspects.

Even if bildung today is often understood in neo-liberal economic terms, we follow in this article the traditional humanistic concept of bildung according to Wilhelm von Humboldt $[15,16]$ and see bildung as personality development in the sense of a human development through the connection between self and world. In contrast to apprenticeship as a process of ability, bildung is understood as a process of becoming, and the philosopher Peter Bieri points out that education in the sense of instruction [Ausbildung] has the aim of being able to do something, to master skills and to perform tasks, while education in the sense of bildung means to become somebody [17].

This process of becoming, of growing up, and of growing in the world is primarily an individual process, but it strongly depends on the circumstances in which somebody lives and grows up. While the people and the world around us provide crucial impulses and help, each person is responsible for how they interact and what they make out of their situation. Summer camps allow participation in nature activities, and although these have a predetermined framework, their approach and outcome remain open.

Reflecting on how bildung is realized, Gerd E. Schäfer defines five characteristics of bildung: (1) Bildung is connected with self-activity. It is not possible to be educated, you have to educate yourself. (2) Bildung is based on individual finding or losing of meaning; this meaning can only be found by oneself, not be conveyed to others. (3) Meaning only results from what someone experiences or does, and from what someone has experienced and done so far. (4) This understanding includes that education is not limited to a rational- 
logical process alone but naturally includes the entire human range of sensory-emotional experience and processing possibilities. Finally, it means (5), that someone always is educated by something, in other words that the objects of bildung bear the stamp of history [18].

The main point expressed in this understanding is that bildung always means selfbildung. Bildung is something subjective, based on self-activity, but, of course, in dependence on and in interaction with others or with the environment. Both rational considerations and sensory experiences can lead to a search for meaning. However, this search for meaning is difficult to convey directly and can only be initiated. Everyone has to find it for themselves. A successful didactic implementation of this understanding of bildung can be found in a humanistic education, which has recently experienced an international renaissance in a (neo-) existentialist variant described by Gert Biesta $[19,20]$. His criticism of the "learnification" of upbringing and bildung, his demand to disconnect teaching and learning, as well as his emphasis on the unpredictability of upbringing and bildung open up a wealth of perspectives for looking at summer camp experiences in terms of their potential for development and bildung. Can such stimuli and impulses for bildung be identified in summer camps? And how are they perceived, described, and experienced by the participants?

\section{A Closer Look into the Empirical Material}

Our empirical material consists of ten interviews with participants of summer camps for children between ten and fourteen years old, attending camps from Soviet times until today's Russia. The study was conducted in 2020, and the informants, who live in the Murmansk region, were randomly selected from a group of people in higher education, mainly women from the age of twenty-two till fifty-nine. They answered the same five questions, some in short and with few sentences, others in longer passages. As an overall impression, most of the participants had vivid and pleasant memories from the camps; only one was skeptical and did not want to recommend it to children today. The questionnaire starts with an invitation to tell about places, events, activities, and attributes while the next one calls upon reflections on the teaching aspect in the life of the camps. They are followed by a question about lessons for life learned, and the last question focuses on what they will tell about camps to a child going there for the first time. The final question was how to guide students who will be future counselors and what to say to parents. From what kind of perspective they articulate their reflections, whether as a child, or as a (skilled) adult, we cannot know, except for the fact that our data are retrospective, and layer upon layer put on, under, and between experiences from a summer long gone.

In the book Metodefestival og øyeblikksrealisme-eksperimenterende kvalitative forskningspassasjer [21], Norman Denzin advocates an attitude of performance, declaring that "the goal is always to create conditions for a critical consciousness, one that imagines a radical politics of possibility" [22] (p. 14). This goes along with an article by Biesta in the same book elaborating on the need of being pragmatic, and not getting lost in theories. He reminds us of having in mind the settings theories occur in and what kind of particular question they were designed to answer. To set his argument, he examines the types of purposes research may have: explanation, understanding or emancipation, and claims this to be more important than being qualitative or quantitative data. This is vital for understanding our material. Those who answered did not have much time to neither prepare nor to give detailed answers. The questions are like an enquete, or 'ten on the street'. However, the informants responded because of their specific experience from participating in summer camps, and they are colleagues in academia, which means that they have access to an educational vocabulary. For the purpose of explaining, this material would be of limited strength, but for an understanding of how these data can be interpreted, we need a theory providing relevance. The emancipatory aspect links to Marx' reflection on the actor's false or inaccurate understanding of their situation, being part of a critical research tradition. Biesta suggests an integration of the different purposes in order to see how 
the stories interact by power in action [23]. As Foucault defines it, power is everywhere, operates in many different kinds of relationships, is always there, and we are never able to put ourselves outside [24]. So, what can we hope for? What are the purposes of the common research? What can theory do to this material? The goal lies in the possibilities of opening up imaginations of broader understandings, expanding on being in infinite and incomplete patterns of knowledge creation. We will seek openings in the material along with a discussion of the concepts of qualification, socialization, and subjection. Our approach is that qualification will be least important, whereas summer camps do not aim at bringing forth a set and formalized system of knowledge. This perspective on educational questions defines qualification as equipping individuals with the knowledge required for citizenship, cultural life, and working life. Socialization, through transformation of norms and values, incorporates an individual into a social order. Subjectification is the process of being oriented toward the individual's freedom, own voice, and uniqueness [19].

The complete list of questions is:

(1) What places, events, and activities in the children's (health, pioneer) camp do you particularly remember and why?

(2) Did you keep any attributes (artifacts) of life in the camp? Tell us about them.

(3) What did life in the camp teach you/what lessons did you learn from life in the camp?

(4) What would you wish for someone who is going to spend time in the camp for the first time?

(5) What kind of guidance would you give to students as future counselors who themselves may not have been in the camp and do not represent its life?

(6) What would you say to parents who are not sure whether it is worth sending their child to a camp?

Despite the informal language in the answers, they nevertheless contain meaning in a pedagogical sense. The respondents, chosen because of their experience from participating in summer camps, are also trained educators, which means that they have access to an educational set of perspectives we have in common. Being skilled in this way means to have a set of theories for approaches to knowledge, children, and society. We do not know their intentions, but we do know they are able to create and assess both teaching and learning situations. As Bruno Latour puts it, when discussing religious faith from the point of no longer sharing the faith, but still understanding the language: "Well, this belief in belief is something that those inside share with those outside-it's actually how they manage to distinguish the inside from the outside" [25] (p. 3). As sharers of the same pedagogical language, even though a closer investigation probably would reveal differences, still we are able to hear what is inside and what is outside and we will now take a closer look on some of the answers to question five, in order to find elements of a pedagogical understanding of learning:

"What kind of guidance would you give to students as future counselors who themselves may not have been in the camp and do not represent its life?"

This question appears as a matter of how a trained person, a colleague, will guide beginners into the educational field in summer camps. This is the answer where we can be on familiar ground because the question is made of words such as 'guidance' and 'students as future counselors', phrases that are part of common educational language. Two respondents were picked out because they were the only ones that in their articulation made use of the words offered in the question or other words from the educational field, for example quality. The way we have understood their statements is the following (Table 1): 
Table 1. Statements by the informants about pedagogical questions.

\begin{tabular}{lll}
\hline \multicolumn{1}{c}{ Qualification } & \multicolumn{1}{c}{ Socialization } & \multicolumn{1}{c}{ Subjectification } \\
\hline $\begin{array}{l}\text { Take responsibility for your work, } \\
\text { be an example for your students, }\end{array}$ & $\begin{array}{l}\text { be interested in quality } \\
\text { recreation for your } \\
\text { students as well as for } \\
\text { yourself } \\
\text { but be an old friend } \\
\text { First of all, do not get into the role } \\
\text { of a dictator, and do not show } \\
\text { familiarity with the children, }\end{array}$ & $\begin{array}{l}\text { and talk to them more often } \\
\text { about moral issues especially } \\
\text { before going to bed, in the } \\
\text { dark (female 42) } \\
\text { be attentive to the children for } \\
\text { advice, and }\end{array}$ \\
\hline
\end{tabular}

Qualification suggests that there is something to do, whereas socialization and subjectification are modes of being with others. Biesta, working on the education's "why" argues in the book The Beautiful Risk of Education that the crucial question of learning is, "whether we lend anonymous metaphysical power to the idea of learning or whether we seize this power in order to make learning as strong or as weak as we want it to be" [19] (p. 76). By being weak, he means unpredictable, quite different from what those outside a pedagogical language, such as policy makers, aim at. The risk is so to say the pedagogy of events rather than essence; "how wonderful it is to live in a team," as a respondent said.

For being a risky task, "sometimes these ways of expressing themselves require a lot of patience to deal with," Francis Fukuyama has warned against an expression leading to identities without link to global understandings of dignity, based upon analyses and critique of economic structures [26]. In other words, the being rather than the doing is an ongoing process without set answers, involving both the self and the world, interacting in ways that are impossible to clearly set apart. The big questions are always present, performative, and powerful in every relation, as an encounter of events. In the following, we will have a specific investigation on events, while digging in relations as encounters with materialities.

\section{Learning from Direct Encounters with Material “Objects”-A Thing-Oriented Approach}

The informants describe summer camps as events in special places. The empirical data show multiplicity in time and space, two fundamental categories that have undergone important shifts over the past decades. In classical social science theory, space and place have been associated with the traditional and stagnant—a form of passive background frame for social processes [27]. With the concept of "sense of place", for example, the experiential aspect of the concept of place was emphasized, where space becomes place when the individual connects something and assigns meaning to it. Eventually, place was not seen as a static framework for social interaction, but as something that is continuously created and recreated as part of social activity. In the wake of the so-called "spatial turn" in the 1990s, the concept of place has gained a central place in the social sciences and the humanities [28].

Place is still a multifaceted concept, and there can be wide variations in the ways in which one perceives and experiences place. Doreen Massey furthered the understanding of the concept of place. She sees places as network-based meeting places of material, social, and cultural relationships that extend far beyond the local. She argues for understanding places as relational events [29]. "A place can be seen as a specific articulation of social practices, social relations, and materiality as well as experiences, narratives, and symbolic meanings of the place held by its different users" [30] (p. 16). Places as meeting places focus on the relational, where the social and the material meet. The focus here is the material side of social life and learning, the relation between human and non-human. The current development of a material turn in social sciences and humanities has influenced the focus towards "the way we move knowledge forward in order to access things ... " [31] (p. 139). We will find out how different users of summer camps were thinking and how they were interacting with materiality in their learning process. The focus here is on entanglements 
between humans and the many things. The term thing replaces the term object to transcend its passive role in the relationship. Things are traces of the past-recent or remote. Things can also be agents [31-34]. A thing-oriented perspective has had little support in learning theories, a question may be how do we learn from direct encounters with things and their materiality?

Some utterances in our data are about the relationship with things. The informants' range in age from 22 to 59 years. Several of them think back to summer camps during the Soviet era. The past plays into contemporary place constructions where experiences of place can vary according to which past elements people emphasize. Events and memories associated with place are an important part of contemporary place construction. Studying relationships between place and past can involve looking more closely at what from the past that is drawn out, especially in relation to some local material things triggering memories. When asked in the survey about what places, events, and activities they particularly remember and why (see questions 1 and 2), several informants highlighted the relation to material things as foundation in their present constructions. One informant stated: "I remember meetings, morning and evening, held on the ship that served as a deck of our common home". Informants mentioned material places where social events took place, and these various mobilities were intertwined in different ways. Things undoubtedly gain importance through the connections in which they are entangled. In relation to this example, the boat also became an important actor in the relational network that took place; it had the capacity to mediate relations and differences between people [34]. It was not further reflected in the interviews why specific material things were mentioned.

The students in summer camps had different camp duties. Among other things, they had kitchen duties, another place where learning took place. The material design and equipment of the kitchen had influence on how interaction could take place. A kitchen will be lost in relation to social events without a system of countertops, sink, oven, knives, cups, etc. We can ask how many different types of actors were gathered and mobilized in creating dinner in the kitchen. Things act as mediators and actors that form many and complex relations. From a thing-oriented perspective, they act together as entangled assemblages [32,34]. In any event, dinner would have been impossible to implement without the collaboration with things.

Things are not enslaved by the social; they also exist independently of human subjects, but things can also instruct and resist in the social relationship [35]. A chair asks you to sit and a door handle tells you to grab hold. We drink a glass of water but rarely reflect on the role of the glass. Things are incorporated into daily life and are easily overlooked if we do not open our field of vision and reflect. The informants remembered different tasks that they learned in relation to things, for example cleaning shoes, combing hair, and making beds. Shoes, comb, and bed will be included in the activity, and in many ways instruct the action. One informant remembers rafting on the river. What was learned in relation to the boat-or what did the boat teach the informant? In a thing-oriented philosophy, we could ask how the informant moved among things and become moved by them. He learned through encounters with things [33,34]. We can say that Martin Heidegger in his object-oriented philosophy broke with the dichotomy of das Ding für uns/das Ding an sich that emerged in Immanuel Kants 'Kritik der reinen Vernunft'. Heidegger spoke of things in terms that they almost absorb the whole world. We can say that the sound, smell, and touch of things create a closeness to the world, by resorting to a range of senses, when symmetry emerges in our common being in the world [33,36]. Little of this appears in the survey, but one informant mentions the first encounter with Pepsi-Cola produced by Novorossiysk plant of soft drinks, where the taste linked to the thing became an everlasting memory.

In relation to question (2):

Did you keep any attributes (artefacts) of life in the camp? Tell us about them.

Some of the participants at summer camps had also brought home memory artefacts such as a t-shirt, certificates of honor, instructor's ties that they have taken care of over time. 
Things intrude into the present, where the past and present intermingle in the production of cultural memory. Archaeologists analytically engage with the role of things in memory and the interplay between materials and time. Things that have been around and endured can invite one to the making of stories. The study of memory is about how humans perceive and grapple with time [37]. One informant had lost a pioneer tie with autographs from other participants at the camp, but the thing and event continue to be a part of social consciousness and have had a role in memory across time and space. The informants' social memory is spatially situated, evoked by and associated with particular places. Things can evoke stories, and memories are triggered in the face of things. The materiality of things invites stories, familiarity, belonging, and change. Things are something more permanent than one had assumed: "Things are more persistent than thought; they evidently last longer than speech and gestures. Things are concrete and offer stability [ ... ] things are normally in place, at least enough of them to make our existence predictable and secure" [38] (p. 136). Things speak by being a more stable factor in existence. The speech of things must be understood metaphorically, an implied communication between subject and thing.

The informants remember different historical memory places, such as visiting the Royal mounds and the Adzhimushkay quarries, excursion to Krasnaya Polyana, "The Pearl of Russia camp" in Anapa. Imagine what historical places have been without things from the past, and the complex interactions between humans and things. Traces recent or remote, our world is a multitemporal palimpsest of durable material things that pile up, overlap, and intrude into the present [39]. There is a focus on the complex human-thing interrelations in the summer camps. Much work remains in addressing the problem of seeing tangible things not as rich traces, but as mere illustrations subordinate to arguments they derive from other sources. How we understand things and how we conceive of their being will also affect their epistemological potential as sources. Things have been marginalized in the social sciences [38]. Agency in western philosophy is linked to human action. The aim for pupils is to acquire a knowledge of things. How we understand things, how we conceive of their being (i.e., ontology) will also affect their epistemological potential. The encounters with things have to become constructive also for learning theories and bildung. Humans are always a part of and interact with other bodies, nature, structure, materiality, etc. It can be argued that it is easier to learn, remember, and let go of something we ourselves have seen, touched, smelled, or tasted [40]. Summer camps provide opportunities for learning together and can create awareness of various and multiple relational settings, also related to everyday life in our being in the world.

\section{Preliminary Reflections: Some Remarks at the End}

Undoubtedly, a camp is a special environment, arranged according to laws different from school. However, it would be wrong to contrast one with the other. Having described the pedagogical intentions of the summer camp, it is to understand how the camp and the school complement each other and help to achieve a balance in the bildung of children, making up for deficiencies. A camp means a social community that develops in a relatively short period from a weakly internally organized and rather formal association based on a common space and time to a collective that has common goals and moral norms, rules of relationships, and long-term attachments.

For the organization of camp activities, it is important to create the optimal ratio of collective and individual. In creating the conditions for socialization, the creation of a collective identity, one must not forget the inherent individuality in every person and that an individual personality is formed through dialogue, interaction, and conflict with others. This means that individuality and collectivity, although they represent opposite poles of a cultural dimension, are both necessary for the formation of personality. Keeping this balance is not an easy task, as Shatsky noted: "Our most important work should be aimed at preserving what is in children. And this is obviously incredibly difficult by its very nature" [41] (p. 44). The relationship between the collective and the individual is further emphasized by Artur Petrovskii [42], who argues that acceptance in the collective and high 
social status forms the individual who has something that others do not have, but it is something important because it means to achieve a common goal.

Here, it is also useful to include the approach of Anatolii Lutoshkin [43], considering the problems of the emotional life of the children's team. He argues that shared experiences are a trigger mechanism that ensures the unity of goals and ways to achieve them, which, in turn, facilitates the formation of collective relationships based on cooperation. For the development of cooperation, it is also important for everyone to fulfill significant social roles, when everyone has their own field of responsibility and regulates the actions of others, while in other actions they themselves are subordinate to someone else. Thus, each individual is both a leader and a performer.

However, the role of the summer camp is not limited to the development of children's relationships. No less important is the development of children's horizons, the acquisition of practical skills during travel, excursions, working in the garden, picking mushrooms, collecting berries, etc. An open space is created that allows children to interact with the environment, in a non-directed form, when they themselves select the content and methods of their cognitive and practical activities and do not act within a strict framework of academic subjects. Thus, there is an opportunity for experimentation, conducting experiments on the basis of which they learn their capabilities, realize their aspirations, interests, and not just about the environment. Last but not least, several of the interviewed subjects describe the emotional impact of the camp, the feeling that there is life before the camp and another one after the camp.

The aim of this article is to provide elements of an emerging theoretical framework to analyze the camps' pedagogical and cultural significance and attraction. In our time of growing economic instrumentalization of education, education in a broad sense, bildung, is sometimes forgotten. There is a risk that an abstract notion of education, realized technologically as online teaching, obfuscates the importance of place and nature, the material setting for education. The fragmentation of learning in the fashionably quantifiable skills and competences approach glosses over the fact that learning is a continuous yet not fully predictable dialogue with the material and social worlds. Identity politics shortcircuits the formation of personality with its focus on being rather than becoming. The expressive and attention-seeking individualism of identity politics merges with a utilitarian "what's in it for me" individualism, and the end-product of this socialization is the atomized consumer, ignoring the mutual creation of individual personality and collective identity. The attraction of summer camps is based on their temporal and spatial limits, creating spaces of play and experimentation for children, teachers, and students. Summer camps are not relics of the past but can be seen both as supplements or as ideal types used to criticize educational orthodoxies both in the past and today.

Author Contributions: Conceptualization, W.B.; H.Z.; T.K.; V.C.; I.A.; T.G.E.; K.E.S.; methodology, W.B.; H.Z.; T.K.; V.C.; I.A.; T.G.E.; K.E.S.; formal analysis, T.G.E. and K.E.S.; writing—original draft preparation, W.B.; H.Z.; T.K.; V.C.; I.A.; T.G.E.; K.E.S.; writing—review and editing, W.B.; H.Z.; V.C.; T.G.E.; K.E.S.; project administration, W.B.; H.Z.; V.C.; K.E.S. All authors have read and agreed to the published version of the manuscript.

Funding: This research received no external funding.

Institutional Review Board Statement: The study was conducted ac-cording to the guidelines of the Declaration of Helsinki, and approved by the Institutional Review Board of Murmansk arctic state university (Protocol No. 1 of 23 September 2020).

Informed Consent Statement: Informed consent was obtained from all subjects involved in the study.

Data Availability Statement: The study did not report any data.

Conflicts of Interest: The authors declare no conflict of interest. 


\section{References}

1. Dinke, D.V. Summer Labor School Camps of the Early 1960s as Enclaves of Soviet Idealism. Vestnik Permskogo universiteta. Istoria 2013, 2, 138-146.

2. Pfaller, R. Erwachsenensprache: Über ihr Verschwinden aus Politik und Kultur; Fischer: Frankfurt am Main, Germany, 2017.

3. Foucault, M. Of Other Spaces. Diacritics 1986, 16, 22-27. [CrossRef]

4. Türcke, C. Lehrerdämmerung: Was die neue Lernkultur in den Schulen Anrichtet; C.H. Beck: Munich, Germany, 2016.

5. Vernadskii, V.I. Ocherki i Rechi (Essays and Speeches); Issue 2, Part II; Scientific Chemical and Technical Publishing House: Moscow, Russia, 1922.

6. Polyakova, L.V.; Kodzhaspirova, G.M. (Eds.) Sovremennoye Obrazovaniye v Strane: Sostoyaniye, Problemy, Perspektivy Razvitiya: Materialy Gorodskogo Mezhvuzovskogo Kruglogo Stola. (Modern Education in the Country: State, Problems, Development Prospects: Materials of the City Interuniversity Round Table); Econ-Inform: Moscow, Russia, 2017.

7. Krupskaya, N.K. O Kommunisticheskom Vospitanii Shkol'nikov: Sbornik Statey, Vystupleniy i Pisem. (On the Communist Education of Schoolchildren: Collection of Articles, Speeches and Letters); Grekova, O.I., Ed.; Prosveshchenie: Moscow, Russia, 1987.

8. Pomelov, V.B. Sto Velikikh Pedagogov. (One Hundred Great Teachers); Veche: Moscow, Russia, 2018.

9. Hahn, K. Reform mit Augenmaß. Ausgewählte Schriften eines Politikers und Pädagogen; Hrsg. von Michael Knoll; Klett-Cotta: Stuttgart, Germany, 1998.

10. Shatsky, S.T. Novaya Obshhestvenno-Pedagogicheskaya Rabota Dlya Detej-Rabotnikov Budushhego. In Pedagogical Works in 4 Volumes. T. 2.; Shatsky, S.T., Ed.; Prosveshchenie: Moscow, Russia, 1964; pp. 272-286.

11. Mayer, J. Die Natur der Erfahrung und die Erfahrung der Natur. In Naturerfahrung. Wege zu einer Hermeneutik der Natur; Gebauer, M., Gebhard, U., Eds.; SFG-Servicecenter Verlag: Kusterdingen, Germany, 2005; pp. 234-258.

12. Kellert, S.R.; Wilson, E.O. The Biophilia Hypothesis; Island Press: Washington, DC, USA, 1993.

13. Fromm, E. Die Seele des Menschen. Ihre Fähigkeit zum Guten und zum Bösen. In Erich-Fromm-Gesamtausgabe (GA) Bd. II; Funk, R., Ed.; dtv: München, Germany, 1999.

14. Fromm, E. Anatomie der menschlichen Destruktivität. In Erich-Fromm-Gesamtausgabe (GA) Bd. VII; Funk, R., Ed.; dtv: München, Germany, 1999.

15. von Humboldt, W. Bildung und Sprache; Schöningh: Paderborn, Germany, 1997.

16. Benner, D. Wilhelm von Humboldts Bildungstheorie; Juventa: Weinheim, Germany, 2003.

17. Bieri, P. Wie wäre es gebildet zu sein? In "Was den Menschen eigentlich zum Menschen macht." Klassische Texte einer Philosophie der Bildung; Lessing, H.U., Steenblock, V., Eds.; Karl Alber: Freiburg, Germany, 2010; pp. 203-218.

18. Schäfer, G.E. Bildungsprozess im Kindesalter. Selbstbildung, Erfahrung und Lernen in der frühen Kindheit; Beltz: Weinheim, Germany, 1995.

19. Biesta, G. The Beautiful Risk of Education; Routledge: New York, NY, USA, 2013.

20. Biesta, G. The Rediscovery of Teaching; Routledge: New York, NY, USA, 2017.

21. Otterstad, A.M.; Reinertsen, A.B. (Eds.) Metodefestival og Øyeblikksrealisme-Eksperimenterende Kvalitative ForskningspassasjerExperimental Qualitative Research); Fagbokforlaget: Bergen, Norway, 2015.

22. Denzin, N.K. The Collapse of Writing. In Metodefestival og Øyeblikksrealisme-Eksperimenterende Kvalitative Forskningspassasjer; Otterstad, A.M., Reinertsen, A.B., Eds.; Fagbokforlaget: Bergen, Norway, 2015; pp. 13-16.

23. Biesta, G. No paradigms, no fashions, and no confessions. Why researchers need to be pragmatic. In Metodefestival og Øyeblikksrealisme-Eksperimenterende Kvalitative Forskningspassasjer; Otterstad, A.M., Reinertsen, A.B., Eds.; Fagbokforlaget: Bergen, Norway, 2015; pp. 133-149.

24. Ball, S.J. Foucault, Power and Education; Routledge: London, UK, 2013.

25. Latour, B. Rejoicing or the Torments of Religious Speech; Polity Press: Cambridge, UK, 2013.

26. Fukuyama, F. Identity. Contemporary Identity Politics and the Struggle for Recognition; Profile Books: London, UK, 2019.

27. Massey, D. A global sense of place. Marx. Today 1991, 38, 24-29.

28. Hubbard, R.; Kitchin, R.; Valentine, G. Key Thinkers on Space and Place; SAGE Publications: Thousand Oaks, CA, USA, 2004.

29. Massey, D. For Space; Sage: London, UK, 2005.

30. Simonsen, K. Place as encounters: Practice, conjunction and co-existence. In Mobility and Place. Enacting Northern European Peripheries; Bærenholdt, J.O., Granås, B., Eds.; Ashgate Aldershot: Burlington, UK, 2008; pp. 13-25.

31. Latour, B. Can We Get Our Materialism Back, Please? Isis 2007, 98, 138-142. [CrossRef]

32. Latour, B. Reassembling the Social-An Introduction to Actor-Network-Theory; Oxford University Press: Oxford, UK, 2005.

33. Olsen, B. Symmetrical archaeology. In Archaeological Theory Today; Hodder, I., Ed.; Polity Press: Cambridge, UK, $2012 ;$ pp. $208-228$.

34. Olsen, B. History of Things: Commentary. In Debating New Approaches to History; Tamm, M., Burke, P., Eds.; Bloomsbury Academic: London, UK, 2018; pp. 232-238.

35. Webmoore, T.; Witmore, C.L. Things Are Us! A Commentary on Human/Things Relations under the Banner of 'social' Archaeology. Nor. Archaeol. Rev. 2008, 41, 53-70. [CrossRef]

36. Andersson, D.T. Tingens Taushet, Tingenes Tale; Solum Forlag: Oslo, Norway, 2001.

37. Pétursdóttir, P.; Olsen, B.J. Theory Adrift: The Matter of Archaeological Theorizing. J. Soc. Archaeol. 2017, 18, 97-117. [CrossRef]

38. Olsen, B. Defense of Things. Archaeology and the Ontology of Objects; Alta Mira Press: Lanham, MD, USA, 2010. 
39. Hamilakis, Y. Archaeology and the Senses: Human Experience, Affect and the Senses; Cambridge University Press: Cambridge, MA, USA, 2013.

40. Østern, T.P.; Dahl, T.; Strømme, A.; Petersen, J.A.; Østern, A.-L.; Selander, S. Dybdelæring-en flerfaglig, relasjonell og skapende tilnærming; Universitetsforlaget: Oslo, Norway, 2019.

41. Shatsky, S.T.; Shatskaya, V.N. Sokhranim to, Chto Yest' v Detyakh. (Let's Preserve What is in Children); Karapuz: Moscow, Russia, 2011.

42. Petrovskii, A.V. Lichnost'. Deyatel'nost' (Personality. Activity. Group). Kollektiv; Publishing House of Political Literature: Moscow, Russia, 1982.

43. Lutoshkin, A.N. Kak Vesti za Soboj: Starsheklassnikam ob Osnovah Organizatorskoj Raboty (How to Lead: For High School Students about the Basics of Organizational Work), 3rd ed.; Prosveshchenie: Moscow, Russia, 1986. 